\title{
Effects of special education teachers' specialization and teaching experience on using evidence-based cognitivist instructional strategies in Inclusion Classrooms
}

\author{
Zaid Al Shammari ${ }^{1 *}$, Paula E. Faulkner ${ }^{2}$ \\ ${ }^{1}$ Kuwait University, Kuwait \\ ${ }^{2}$ North Carolina Agricultural and Technical State University, USA
}

\begin{abstract}
Evidence-based instructional strategies are considered fundamental for educating students with special needs. The use of study skills is an instructional strategy is considered beneficial as students can locate, organize and recall concepts. This study's main purpose was to measure the effect of special education teachers' qualification for using evidence-based strategies in Kuwait's public elementary inclusive schools. The study's research was three-fold which was to: (1) determine the effect size of evidence-based congnitivism instructional strategies (e.g., study skills, concept mapping, and reciprocal teaching), (2) measure the effects of special education teachers' education qualifications and teaching experiences on using evidence-based congnitivism instructional strategies, and (3) provide recommendations for administrators and special education teachers in Kuwait's public elementary inclusion schools. Data were collected using a questionnaire that found reciprocal teaching the most important strategy. It was concluded that while there were no significant differences found in teacher' educational qualifications, there were significant differences in teachers' teaching experiences. Based on these conclusions, the following recommendations were made which include: providing specialized professional training workshops for special education teachers, specifically addressing qualifications which are not special education related and changing recruitment policies and requirements for teachers who specialize in teaching students with special needs in inclusive classrooms.
\end{abstract}

Keywords: cognitivism, inclusion, instructional strategies, special education 


\section{Introduction}

Evidence-based instructional strategies are currently fundamental keys in the education of students with special needs. In specific, Mitchell (2014) specified 20 evidence-based strategies used in special education and inclusive education classrooms. Hattie (2017) provided an effect size for each evidence-based instructional strategy, while Hornby (2014) added that there are three most extensively researched evidence-based cognitivism instructional strategies that can be implemented in the classrooms with students with special education needs (SEND). These evidence-based congnitivism-based instructional strategies were selected to conduct the current research. Each strategy is described as follows.

The study skills include ways that students can locate, organize and recall concepts. Line drawing and pictures are more easily comprehended for abstract concepts than complex definitions (Terry, 2003). Features of the instructional approach for study skills include: note taking, highlighting information, creating a "to do" list, following a schedule, and setting aside time to complete study and work (Chang \& Ku, 2015). Concept mapping is "described repeatedly in the literature as a tool that can support and enhance students' learning" (Kinchin, 2001). To teach concept mapping, students must learn to graphically organize information being taught into diagrams. And, reciprocal teaching is "a scaffolded technique based on teacher modeling, student participation, and four strategies that good readers use to comprehend text: predicting, questioning, clarifying, and summarizing" (Oczkus, 2003).

\section{Purpose and Objectives of the Study}

The purpose of this research study is three-fold which is: (1) to determine the effect size of evidence-based congnitivism instructional strategies (e.g., study skills, concept mapping, and reciprocal teaching), (2) to measure the effects of special education teachers' education qualifications and teaching experiences for using evidence-based congnitivism instructional strategies in the inclusive classroom, and (3) to provide recommendations for administrators and special education teachers in Kuwait's public elementary inclusion schools.

\section{Methods}

A descriptive research design was conducted in Kuwait's public elementary inclusion schools. Data were collected using a questionnaire consisting of 14-statements with research variables such as study skills, concept mapping, and reciprocal teaching. The researchers then analyzed the data and reported using descriptive and inferential statistics (e.g. means, standard deviation, frequencies, and t-test). The participants consisted of 46 participants, which included special education math teachers $(n=27)$ and science teachers $(n=19)$ who randomly selected for this research purpose. 


\section{Results}

The study's results from the data collection and analyzes revealed teachers' based on specialized qualification, most desired strategy was reciprocol teaching ( $M=2.95$, mathematic teachers and $M=2.84$, science teachers), while for teacher experience revealed the same $(M=3.41,5$ years or less and $M=2.69,6$ years or above. Contrastly, Concept mapping was revealed as the least instructional strategy based on teaching experience and qualification. (See Tables 1 and 2).

\section{Table 1.}

Means, Standard Deviation, Frequency, and T-test according to Special Education Teachers' Education Qualifications

\begin{tabular}{|c|c|c|c|c|c|c|}
\hline Strategy & $\begin{array}{l}\text { Teacher } \\
\text { Specialized } \\
\text { Qualification }\end{array}$ & $f$ & Mean & SD & $\mathrm{T}$ & Sig. \\
\hline \multirow{2}{*}{ Study Skills } & Mathematics & 27 & 2.51 & 0.70 & \multirow{2}{*}{-.376} & \multirow{2}{*}{.708} \\
\hline & Sciences & 19 & 2.59 & 0.69 & & \\
\hline \multirow{2}{*}{ Concept Mapping } & Mathematics & 27 & 1.96 & 1.00 & \multirow{2}{*}{-1.107} & \multirow{2}{*}{.274} \\
\hline & Sciences & 19 & 2.28 & 0.99 & & \\
\hline \multirow{2}{*}{ Reciprocal Teaching } & Mathematics & 27 & 2.95 & 0.89 & \multirow{2}{*}{.419} & \multirow{2}{*}{.677} \\
\hline & Sciences & 19 & 2.84 & 0.89 & & \\
\hline \multirow{2}{*}{ Total Degree } & Mathematics & 27 & 2.44 & 0.68 & \multirow{2}{*}{-.548} & \multirow{2}{*}{.586} \\
\hline & Sciences & 19 & 2.55 & 0.71 & & \\
\hline
\end{tabular}

Table 2.

Means, Standard Deviation, Frequency, and T-test according to Special Education Teachers' Years of Teaching Experience

\begin{tabular}{|l|l|l|l|l|l|l|}
\hline Strategy & $\begin{array}{l}\text { Teacher Years of } \\
\text { Teaching } \\
\text { Experience }\end{array}$ & $f$ & Mean & SD & T & Sig. \\
\hline
\end{tabular}


International Conference on Research in Education, Teaching and Learning

Paris, France| April 19-21, 2019

\begin{tabular}{|c|c|c|c|c|c|c|}
\hline \multirow[b]{2}{*}{ Study Skills } & 5 years or less & 14 & 3.01 & 0.45 & \multirow[b]{2}{*}{3.41} & \multirow[b]{2}{*}{.001} \\
\hline & $\begin{array}{l}6 \text { years and } \\
\text { above }\end{array}$ & 32 & 2.34 & 0.68 & & \\
\hline \multirow[b]{2}{*}{ Concept Mapping } & 5 years or less & 14 & 2.84 & 0.96 & \multirow[b]{2}{*}{3.89} & \multirow[b]{2}{*}{.000} \\
\hline & $\begin{array}{l}6 \text { years and } \\
\text { above }\end{array}$ & 32 & 1.76 & 0.83 & & \\
\hline \multirow[b]{2}{*}{ Reciprocal Teaching } & 5 years or less & 14 & 3.41 & 0.81 & \multirow[b]{2}{*}{2.74} & \multirow[b]{2}{*}{.009} \\
\hline & $\begin{array}{l}6 \text { years and } \\
\text { above }\end{array}$ & 32 & 2.69 & 0.83 & & \\
\hline \multirow[b]{2}{*}{ Total Degree } & 5 years of less & 14 & 3.07 & 0.56 & \multirow[b]{2}{*}{4.55} & \multirow[b]{2}{*}{.000} \\
\hline & $\begin{array}{l}6 \text { years and } \\
\text { above }\end{array}$ & 32 & 2.23 & 0.58 & & \\
\hline
\end{tabular}

\section{Conclusion and Recommendations}

As the results highlighted the effects of special education teachers' specialization and teaching experience on using evidence-based cognitivism instructional strategies in inclusion classrooms. Results indicated that there were no significant differences found in special education teachers' education qualifications (BA in Curriculum and Instruction, and BA in Special Education). However, significant differences were found in special education teachers' teaching experiences on the three evidence-based cognitivism instructional strategies (study skills, concept mapping, and reciprocal teaching).

Emerging from these findings, this study concluded with some recommendations to school administrators and special education teachers for future improvements in the quality of teaching students with special needs in inclusion classrooms in Kuwait.

First, providing specialized professional development workshops and programs for special education teachers, specifically for those education qualifications are not in the special education.

Second, changing recruitment policies and requirements for special education teaching profession, specifically recruiting those who specialized in teaching students with special needs in inclusion classrooms. 
Last, teacher education programs in education colleges in Kuwait should develop their special education programs aligned with international standards in special education and inclusive education.

Based on the conclusions, the researchers made the following recommendations that while there were not significant differences found with education qualifications, there were significant differences in teaching experiences. Recommendations include: 1-provide specialized professional development workshops for special education teachers, specifically for those education qualifications which are not based in special education, and 2- change recruitment policies and requirements for the special education teaching profession, specificially for recruiting those individuals who specialize in teaching students with special needs in an inclusive setting.

\section{References}

Chang, W., \& Ku, Y. (2015). The effects of note-taking skills instruction on Elementary students' reading. Journal Of Educational Research, 108(4), 278-291.

Hattie, J. (2017). Updated list of factors influencing student achievement. Retrieved from http://www.evidencebasedteaching.org.au/hatties-2017-updated-list/

Hornby, G. (2014). Inclusive special education: Evidence-based practices for children with special needs and disabilities. New York: Springer.

Kinchin, I. M. (2001). If concept mapping is so helpful to learning biology, why aren't we all doing it?. International Journal of Science Education, 23(12), 1257-1269.

Mitchell, D. (2014). What really works in special and inclusive education: Using evidencebased teaching strategies. London: Routledge.

Oczkus, L. D. (2003). Reciprocal teaching at work: Strategies for improving reading comprehension. Newark, DE: International Reading Association.

Terry, W. S. (2003). Learning and memory basic principles, processes, and procedures. 2nd Edition. Boston: Allyn and Bacon. 